\title{
Pengambilan Keputusan Menentukan Jurusan Kuliah Ditinjau Dari Student Self Efficacy Dan Persepsi Terhadap Harapan Orang Tua
}

\author{
Wisnu Prabowo \\ Psikologi, Universitas Sebelas Maret, Indonesia \\ Email:wprabowo26@gmail.com \\ Munawir Yusuf \\ Psikologi, Universitas Sebelas Maret, Indonesia \\ Email:munawir_uns@yahoo.com \\ Rini Setyowati \\ Psikologi, Universitas Sebelas Maret, Indonesia \\ Email:rini.setyowati@gmail.com
}

\begin{abstract}
This study aims to determine the relationship between student self efficacy and perceptions of parents' expectations with decision making in determining the college majors. The research instrument used the scale of decision making to determine the majors $(r=0.868)$, student self efficacy scale $(r=0.858)$, and the scale of perceptions of parents' expectations $(r=0.888)$. The data analysis technique of this study used multiple linear regression. Based on multiple linear regression test, the value of Fcount $=39.116>$ Ftable $=3.06(p=0.000<0.05)$ with a value of $R=0.593$. The total contribution of student self efficacy and perceptions of parents' expectations for decision making determines the course major of 0.352. Based on the partial test, it showed that there are a relationship between student self-efficacy and decision making in determining the majors $(\mathrm{p}=0.43<0.05 \mathrm{rx} 1 \mathrm{y}=0.140)$ and there are a relationship between perceptions of parents' expectations and decision making in determining the majors $(\mathrm{p}=0,000<0,05$; $\mathrm{rx} 2 \mathrm{y}=0,549)$.
\end{abstract}

Keywords: self efficacy; perceptions; parents' expectations; decision making; determine college majors

\begin{abstract}
Absrak. Penelitian ini bertujuan untuk mengetahui hubungan antara student self efficacy dan persepsi terhadap harapan orang tua dengan pengambilan keputusan menentukan jurusan kuliah.. Teknik analisis data penelitian ini menggunakan regresi linier berganda. Berdasarkan uji regresi linear berganda, nilai $\mathrm{F}_{\text {hitung }}=39,116>\mathrm{F}_{\text {tabel }}=3,06(p=0,000$ $<0,05)$ dengan nilai $\mathrm{R}=0,593$. Sumbangan total student self efficacy dan persepsi terhadap harapan orang tua terhadap pengambilan keputusan menentukan jurusan kuliah sebesar 0,352. Berdasarkan uji parsial, menunjukkan bahwa terdapat hubungan antara student self efficay dengan pengambilan keputusan menentukan jurusan kuliah ( $\mathrm{p}=0,43$ $\left.<0,05 \mathrm{r}_{\mathrm{x} 1 \mathrm{y}}=0,140\right)$ dan terdapat hubungan antara persepsi terhadap harapan orang tua memiliki dengan pengambilan keputusan menentukan jurusan kuliah $(\mathrm{p}=0,000<0,05$; $\left.\mathrm{r}_{\mathrm{x} 2 \mathrm{y}}=0,549\right)$.
\end{abstract}

Kata kunci : self efficacy, persepsi; harapan orang tua, pengambilan keputusan; menentukan jurusan kuliah 


\section{PENDAHULUAN}

Masa remaja merupakan masa peralihan dari masa anak-anak ke masa dewasa. Menurut Santrock, 2012, remaja dengan usia 17 - 18 tahun berada pada tahap Identity vs Indentity Cofussion. Apabila pada tahap ini remaja tidak dapat menemukan jati dirinya maka akan mengalami identity confussion atau kebingungan identitas.

Salah satu bentuk permasalahan yang ditemui pada masa remaja ini adalah kebingungan dalam menentukan jurusan kuliah yang akan diambil. Remaja mengalami kebingungan dalam menentukan pilihan dari berbagai macam jurusan di perguruan tinggi yang menawarkan keahlian tertentu pada tiap-tiap jurusan. Hal ini mengakibatkan beberapa individu memilih jurusan yang tidak sesuai dengan dirinya. Berdasarkan penelitian yang dilakukan oleh Indonesia Career Centre Work (ICCN) yang dilansir dari beritasatu.com mengungkapkan bahwa sebagian besar mahasiswa Indonesia mengalami salah jurusan (Makmun, 2017). Hal senada juga diungkap penelitian yang dilakukan oleh Educational Psychologist dari Integrity Development Flexibility (IDF) menyatakan bahwa sebagian mahasiswa Indonesia masuk jurusan yang tidak sesuai dengan dirinya. Sebagian besar mahasiswa masuk jurusan kulliah akibat menuruti keinginan dari orang tuanya tetapi tidak melihat kemampuan dan keinginan dirinya (Saragih, 2016).

Putro (2017), mengatakan bahwa pengambilan keputusan menentukan karir merupakan salah satu tugas perkembangan yang harus dipenuhi oleh remaja. Pengambilan keputusan menentukan jurusan kuliah merupakan salah satu bagian dari penentuan karir di masa depan. Hal ini dikarenakan jurusan kuliah yang dipilih akan menentukan kehidupan individu di masa depan. Karir akan menentukan tingkat finansial, tempat tinggal, pertemanan, dan kesehatan individu. Santrock (2012) mengemukakan bahwa keputusan memilih karir memiliki hubungan positif dengan pencapaian identitas diri. Karir juga dipandang sebagai penentu kelas sosial dalam masyarakat. Masyarakat akan memberikan penghargaan dan status yang tinggi pada individu yang memiliki jabatan atau kedudukan.

Pengambilan keputusan menentukan karir perlu perencanaan yang baik. Hal ini dikarenakan karir akan mempengaruhi kehidupan di masa depan. siswa perlu mengukur kemampuan dirinya sebelum membuat sebuah keputusan memilih karir. Selain itu, peran orang tua masih berkontribusi besar dalam kehidupan siswa sehingga siswa perlu untuk mempertimbangkan pendapat orang tua.

Myers (2012), dalam penelitiannya membahas mengenai sistem keyakinan dalam menyelesaikan tugas. Suatu kepercayaan yang dibangun oleh individu mengenai kompetensi diri merupakan hasil dari penyelesaian tugas yang telah diselesaikan dengan baik. Penelitian yang dilakukan Bandura dan Maddux menyatakan bahwa anak dengan self efficacy tinggi cenderung pantang menyerah dan berprestasi secara akademik (Myers, 2012). Sistem keyakinan yang telah terbentuk akan memberikan dorongan untuk menyelesaikan sebuah tugas secara terorganisir Individu yang sudah memiliki keyakinan diri atas kemampuannya akan memilih jurusan kuliah yang sesuai dengan kemampuan yang ia miliki. Keyakinan akan menggerakkan individu secara terorgansir agar dapat mencapai jurusan yang ia inginkan.

Crisan \& Turda (2015) menemukan bahwa self efficacy yang rendah mengakibatkan individu mengalami kesulitan dalam menentukan karirnya. Self efficacy dapat menjadi prediktor kuat dalam pengambilan keputusan memilih jurusan. Hal ini didukung oleh penelitian yang dilakukan (Riady, 2014) yang menemukan bahwa terdapat hubungan positif antara self efficacy dan pemilihan karir. Semakin tinggi self efficacy maka kemampuan dalam pemilihan karir pada individu juga semakin tinggi.

Aspek self efficacy oleh Schmitz (2013) yaitu Academic Performance merupakan kepercayaan siswa atas kemampuan yang dimiliki dalam menguasai bidang akademik, Skill and Performance merupakan kepercayaan akan penguasaan ketrampilan dan kinerja yang harus dilakukan untuk menyelesaikan sebuah tugas., Sosial Interaction merupakan aspek yang menekankan pada pengaruh lingkungan yang memengaruhi terhadap kepercayaan individu dalam menyelesaikan tugas yang harus diselesaikannya., dan Coping with Academic Stress merupakan Kemampuan koping siswa dalam menghadapi kegagalan atau tekanan dari bidang akademik.

Santrock (2012) menemukan bahwa harapan orang tua mengenai kemandirian anak berbeda-beda bergantung pada budaya, orang tua, dan masa remaja. Orang tua sangat 
berpengaruh dalam pemilihan karir anak pada kebudayaan Timur. Orang tua memberikan pertimbangan atau arahan kepada anaknya untuk memilih jurusan kuliah yang akan diambil. Anak dan orang tua adalah suatu ikatan yang tidak dapat dilepaskan sampai kapanpun. Orang tua harus dilibatkan dalam pengambilan keputusan yang berdampak besar bagi dirinya (Soesandirejo, 2017). Anak yang sudah berusia 18 tahun atau lebih, tetap dipandang tanggung jawab dari orang tua.

Orang tua memiliki pegaruh yang besar dalam pemilihan jurusan kuliah anaknya. Anak mempersepsi keterlibatan dan pengaruh orang tua sebagai hal yang positif dan negatif. Hal positif yang dirasakan yaitu semakin menguatkan anak dalam memilih jurusan kuliah. Hal negatif yang dirasakan adalah kesulitan anak dalam menentukan jurusan kuliah yang diakibatkan oleh rasa cemas dan frustrasi anak (Tilman, 2015). Orang tua sangat berpengaruh dalam membangun self esteem anak yang berkorelasi positif dengan eksplorasi dan perencanaan karir anak (Lim \& You, 2019).

Penelitian yang dilakukan di beberapa negara di Asia menyebutkan bahwa harapan orang tua kepada anaknya sangat memengaruhi dalam pegambilan keputusan karir anak. Leung, Hou, Gati, dan Li (2011) menemukan bahwa parent expectation atau harapan orang tua merupakan faktor yang menyebabkan kesulitan dalam menentukan karir pada remaja. Hou dan Leung (2011) juga menemukan bahwa adanya ketidakcocokan antara harapan orang tua dan anak dalam hal karir menyebabkan anak merasa kesulitan dalam menentukan karir yang akan dijalani.

Berdasarkan uraian di atas dapat disimpulkan bahwa pengambilan keputusan menentukan jurusan kuliah merupakan hal yang penting dalam kehidupan individu. Hal ini dikarenakan pengambilan keputusan individu dalam menentukan jurusan kuliah akan menentukan pula masa depan individu. Pengambilan keputusan menentukan jurusan kuliah dipengaruhi oleh sistem keyakinan individu terhadap kemampuannya atau self efficacy dan persepsi individu terhadap harapan orang tuanya. tujuan dari penelitian ini yaitu mengetahui antara student self efficacy dan Persepsi terhadap harapan orang tua dengan pengambilan keputusan menentukan jurusan kuliah pada siswa SMA.

\section{METODE PENELITIAN}

Populasi penelitian adalah siswa kelas XII di SMAN 3 Magelang yang berjumlah 234 siswa dari 8 kelas. Penentuan besar sampel penelitian menggunakan rumus Slovin dengan $e$ atau error tollerance sebesar 5\% sehingga didapat sampel sebesar 147 siswa. Teknik pengambilan sampel menggunakan teknik cluster random sampling.

Metode pengumpulan data penelitian ini dengan tiga skala psikologi sebagai alat ukur, yaitu skala pengambilan keputusan menentukan jurusan kuliah, skala student self efficacy, dan skala persepsi terhadap harapan orang tua.

Instrumen penelitian menggunakan skala sikap. Skala yaang digunakan adalah skala pengambilan keputusan menentukan jurusan kuliah, skala student self efficacy, dan persepsi terhadap harapan orang tua. Skala pengambilan keputusan menentukan jurusan kuliah terdiri dari 19 item dengan koefisien reliabilitas Cronbach's Alpha sebesar 0,868. Skala student self efficacy terdiri dari 24 item dengan koefisien reliabilitas Cronbach's Alpha sebesar 0,858. Skala persepsi terhadap harapan orang tua terdiri dari 20 aitem dengan koefisien reliabilitas Cronbach's Alpha sebesar 0,888. Teknik analisis data dalam penelitian ini menggunakan regresi linier berganda.

\section{HASIL DAN PEMBAHASAN}

Hasil uji hipotesis dalam penelitian ini menunjukan bahwa terdapat hubungan yang signifikan antara pengambilan keputusan menentukan jurusan kuliah pada siswa SMA

Tabel. 1. Hasil Uji Simultan

\begin{tabular}{llllll}
\multicolumn{7}{c}{ ANOVA $^{\mathbf{b}}$} & & \\
\hline Model & Sum of Squares & Df & Mean Square & F & Sig. \\
\hline Regression & 1675,314 & 2 & 837,657 & $\mathbf{3 9 , 1 1 6}$ & $\mathbf{0 0 0}^{\mathbf{b}}$ \\
\hline Residual & 3083,706 & 144 & 21,415 & & \\
\hline Total & 4759,020 & 146 & & & \\
\hline
\end{tabular}

Tabel hasil uji Regresi Linier Berganda di atas menunjukkan bahwa terdapat hubungan antara student self efficacy dan persepsi terhadap harapan orang tua dengan pengambilan 
keputusan menentukan jurusan kuliah dengan $\mathrm{F}$ hitung sebesar 39,116 sedangkan $\mathrm{F}$ tabel dengan df $(\mathrm{N} 1)=\mathrm{k}-1,2$ dan df $(\mathrm{N} 2)=\mathrm{n}-\mathrm{k}, 144$ adalah 3,06. Dilihat dari data yang telah diperoleh, $F_{\text {hitung }}$ sebesar 39,116 sementara $F_{\text {tabel }}$ dengan signifikansi 0,05 sebesar 3,04, maka $F_{\text {hitung }}>$ $\mathrm{F}_{\text {tabel. }}$. Korelasi antara kedua variabel signifikan dengan nilai signifikansi $p=0,000<0,05$.

Hasil uji parsial menunjukkan bahwa terdapat hubungan antara student self efficacy dengan pengambilan keputusan menentukan jurusan kuliah pada siswa SMA. Hasil ini juga menunjukkan bahwa terdapat hubungan antara persepsi terhadap harapan orang tua dengan pengambilan keputusan menentukan jurusan kuliah dengan pengambilan keputusan menentukan jurusan kuliah pada siswa SMA. Hasil penelitian ini sesuai dengan pendapat Santrock (2012) bahwa harapan orang tua mengenai kemandirian anak berbeda-beda bergantung pada budaya, orang tua, dan masa remaja. Orang tua sangat berpengaruh dalam pemilihan karir anak pada kebudayaan Timur. Orang tua memberikan pertimbangan atau arahan kepada anaknya untuk memilih jurusan kuliah yang akan diambi

Tabel. 2. Hasil Analisis Korelasi Parsial antara Student Self Efficacy dan Persepsi terhadap Harapan Orang Tua dengan Pengambilan Keputusan Menentukan Jurusan Kuliah

Correlations

\begin{tabular}{llccc}
\hline & & $\begin{array}{c}\text { Pengambilan } \\
\text { keputusan } \\
\text { menentukan jurusan } \\
\text { kuliah }\end{array}$ & $\begin{array}{c}\text { Student self } \\
\text { Efficacy }\end{array}$ & $\begin{array}{c}\text { Persepsi } \\
\text { Harapan } \\
\text { Orang tua }\end{array}$ \\
\hline $\begin{array}{l}\text { Pearson } \\
\text { Correlation }\end{array}$ & pengambilan keputusan & 1,000 &, 251 &, 577 \\
\cline { 2 - 5 } & student self efficacy &, 251 & 1,000 &, 202 \\
\hline Sig. (1- & persepsi harapan orang tua &, 577 &, 202 & 1,000 \\
\cline { 2 - 5 } tailed) & pengambilan keputusan &. &, 001 &, 000 \\
\cline { 2 - 5 } & student self efficacy &, 001 &, 007 &, 007 \\
\hline N & persepsi harapan orang tua &, 000 & 147 & 147 \\
\cline { 2 - 5 } & pengambilan keputusan & 147 & 147 & 147 \\
\cline { 2 - 5 } & ptudent self efficacy & 147 & 147 & 147 \\
\hline
\end{tabular}

Tabel uji parsial menunjukkan bahwa terdapat hubungan antara student self efficacy dengan pengambilan keputusan menentukan jurusan kuliah pada siswa SMA dengan $p<001$ $(<0,05)$ dan terdapat hubungan antara persepsi terhadap harapan orang tua dengan pengambilan keputusan menentukan jurusan kuliah dengan pengambilan keputusan menentukan jurusan kuliah pada siswa SMA dengan $p=0,000(<0,05)$.

Sumbangan efektif student self efficacy terhadap pengambilan keputusan menentukan jurusan kuliah adalah 11,6\%. Sumbangan efektif persepsi terhadap harapan orang tua terhadap pengambilan keputusan menentukan jurusan kuliah adalah 23,5\%. Total sumbangan efektif student self efficacy dan persepsi terhadap harapan orang tua ditunjukkan oleh $\mathrm{R}$ square sebesar 0,352 atau $35 \%$. persepsi terhadap harapan orang tua yang merupakan faktor eksternal memiliki pengaruh yang lebih besar dibandingkan dengan student self efficacy.
Berdasarkan hasil kategorisasi, variabel pengambilan keputusan menentukan jurusan kuliah menunjukkan sebanyak $18,4 \%$ responden dalam penelitian ini memiliki tingkat pengambilan keputusan menentukan jurusan kuliah tinggi, $62,6 \%$ responden memiliki tingkat pengambilan keputusan menentukan jurusan kuliah sedang, dan $17 \%$ responden memiliki tingkat pengambilan keputusan menentukan jurusan kuliah rendah. Variabel student self efficacy menunjukkan sebanyak sebanyak $16,3 \%$ responden dalam penelitian ini memiliki tingkat student self efficacy tinggi, 64,6\% responden memiliki student self efficacy sedang, dan 18,3\% responden memiliki tingkat student self efficacy rendah. Variabel persepsi terhadap harapan orang tua sebanyak $19 \%$ responden dalam penelitian ini memiliki tingkat persepsi terhadap harapan orang tua sangat rendah, $65,3 \%$ responden memiliki persepsi terhadap harapan orang tua sedang, dan $13,6 \%$ responden memiliki tingkat persepsi terhadap harapan orang tua rendah. 
Berdasarkan uji hipotesis didapat bahwa terdapat hubungan antara student self efficacy dan persepsi terhadap harapan orang tua dengan pengambilan keputusan menentukan jurusan kuliah pada siswa.

Pengambilan keputusan adalah sebuah proses kompleks yang membutuhkan kemampuan pengorganisasian tujuan, kemung-kinan tindakan di masa mendatang, pengetahuan mengenai kecenderungan, pengetahuan tentang hasil yang akan diharapkan, dan spesifikasi kriteria yang melandasi pegambilan keputusan. Hal ini didukung oleh penelitian yang dilakukan Riady (2014) yang menemukan bahwa terdapat hubungan positif antara self efficacy dan pemilihan karir. Semakin tinggi self efficacy maka kemampuan dalam pemilihan karir pada individu juga semakin tinggi. Faktor keluarga dapat berupa harapan yang dimiliki oleh orang tua. Hal ini didukung oleh Pappas dan Kounenou (2011) yang menemukan bahwa orang tua memiliki pengaruh yang besar dalam pembuatan keputusan karir pada siswa sekolah menengah di Yunani.

Berdasarkan uji korelasi parsial didapat bahwa terdapat hubungan antara student self efficacy dan pengambilan keputusan menentukan jurusan kuliah pada siswa SMA. Bullock (2014) menyatakan bahwa Self-efficacy berkontribusi besar dalam pembuatan keputusan karir sehingga memerlukan perhatikan khusus dari berbagai pihak. Sekolah sebagai institusi yang tempat siswa belajar perlu menyediakan fasilitas konseling dan bimbingan karir pada siswa sehingga siswa tidak mengalami kesulitan dalam menentukan jurusan kuliahnya.

Proses pengambilan keputusan menentukan jurusan kuliah diawali dengan mengidentifikasi kemudian pembuatan alternatif pilihan, dan diakhiri dengan pemilihan satu pilihan jurusan kuliah. Pada tahap ini, self efficacy memiliki peran yang sangat penting. Self efficacy memengaruhi penetapan tujuan individu. Individu dengan self efficacy yang kuat dapat melakukan pengambilan keputusan menentukan jurusan yang tinggi. Self efficacy juga memengaruhi individu dalam proses perencanaan strategi dalam mencapai tujuan atau keputusan yang telah ditetapkan. Hasil penelitian ini juga sesuai dengan penelitian yang dilakukan oleh Reddan (2015) yang menyebutkan adanya pengaruh antara self efficacy dengan pengambilan keputusan menentukan jurusan kuliah.
Berdasarkan uji korelasi parsial didapat bahwa terfapat hubungan anara persepsi terhada harapan orang tua dengan pengambilan keputusan menentukan jurusan kuliah pada siswa SMA. Harapan yang dimiliki orang tua akan dimaknai oleh remaja sehingga memengaruhi berbagai aspek dalam kehidupannya. Harapan orang tua dimaknai sebagai pertimbangan remaja dalam menentukan kehidupan karir di masa depan sehingga pengambilan keputusan menentukan jurusan kuliah sangat dipengaruhi oleh pemaknaan remaja terhadap harapan dari orang tuanya. Hasil penelitian ini sesuai penelitian yang telah dilakukan sebelumnya oleh Fouad et all (2016) yang menemukan bahwa harapan orang tua adalah salah satu bentuk pengaruh orang tua yang sangat penting bagi anak dalam menentukan keputusan dalam dirinya terutama dalam kehidupan karir.. Harapanharapan yang dimiliki orang tua akan dimaknai oleh remaja sehingga memengaruhi berbagai aspek dalam kehidupannya. Salah satu aspek yang terpengaruh adalah pengambilan keputusan menentukan jurusan kuliah. Pengambilan keputusan menentukan jurusan kuliah, menentukan kehidupan karir di masa depan. Harapan orang tua dimaknai sebagai pertimbangan oleh remaja dalam menentukan kehidupan karir di masa depan sehingga pengambilan keputusan menentukan jurusan kuliah sangat dipengaruhi oleh pemaknaan remaja terhadap harapan dari orang tuanya. Hasil penelitian ini turut menguatkan penelitian yang telah dilakukan sebelumnya oleh Kumar (2016) yang menemukan bahwa pengaruh orang tua memiliki hubungan yang signifikan dengan pemilihan jurusan anaknya terutama pengaruh dari ayah.

Hasil penelitian menunjukkan bahwa secara terpisah, persepsi terhadap harapan orang tua yang merupakan faktor eksternal memiliki pengaruh yang lebih besar dibandingkan dengan student self efficacy. Hal ini dapat dijelaskan bahwa pada masa remaja dorongan eksternal memiliki pengaruh yang lebih besar dari pada internal individu. Pada masa ini, remaja masih berada pada masa pencarian jati diri sehingga individu belum menemukan dirinya. Jati diri yang belum terbentuk mengakibatkan kemampuan yang berasal dari dalam individu belum bersifat adekuat sehingga berpengaruh pada sistem keyakinan diri berpengaruh lebih kecil. 


\section{SIMPULAN DAN SARAN}

Berdasarkan analisis dan hasil penelitian yang telah dilakukan diperoleh beberapa simpulan yaitu terdapat hubungan yang signifikan antara student self efficacy dan persepsi terhadap harapan orang tua dengan pengambilan keputusan menentukan jurusan kuliah. Saran yang dapat diberikan sebagai berikut: Pertama, sekolah sebagai institusi pendidikan perlu memberikan fasilitas konseling dan bimbingan karir pada siswanya untuk mengeksplorasi dan merencanakan karir. Kedua, orang tua perlu membangun keyakinan anaknya sehingga siswa mampu memilih dan merencanakan karirnya. Ketiga, siswa perlu untuk mengetahui dan meyakinkan diri mengenai kemampuan yang dikuasai sehingga dapat memilih jurusan yang sesuai dengan kemampuannya. Keempat, siswa perlu mempertimbangkan harapan orang tua mengenai karir ke depan.

\section{DAFTAR RUJUKAN}

Bullock-Yowell, E., McConnell, A. E., \& Schedin, E. A. (2014). Decided and Undecided Students: Career Selfefficacy, Negative Thinking, and Decision-Making Difficulties. NACADA Journal, 34(1), 22-34. https://doi.org/10.12930/NACADA-13016

Crişan, C., \& Turda, S. (2015). The Connection between the Level of Career Indecision and the Perceived Self-efficacy on the Career Decision-making among Teenagers. Procedia - Social and Behavioral Sciences, 209, 154-160. https://doi.org/10.1016/j.sbspro.2015.11 .271

Fouad, N. A., Kim, S., Ghosh, A., Chang, W., \& Figueiredo, C. (2016). Family Influence on Career Decision Making: Validation in India and the United States. Journal of Career Assessment, 24(1), 197-212. https://doi.org/10.1177/1069072714565 782

Hou, Z., \& Leung, S. A. (2011). Vocational aspirations of Chinese high school students and their parents' expectations. Journal of Vocational Behavior, 79(2),
349-360.

https://doi.org/10.1016/j.jvb.2011.05.00 8

Kotler, P., \& Keller, K. L. (2012). Marketing management. Boston, Mass.: Prentice Hall/Pearson.

Kumar, S. (2016). Parental Influence on Career Choice Traditionalism among College Students in Selected Cities in Ethiopia. International Journal of Psychology and Educational Studies, 3(3), 23-30. https://doi.org/10.17220/ijpes.2016.03.0 03

Leung, S. A., Hou, Z.-J., Gati, I., \& Li, X. (2011). Effects of parental expectations and cultural-values orientation on career decision-making difficulties of Chinese University students. Journal of Vocational Behavior, 78(1), 11-20. https://doi.org/10.1016/j.jvb.2010.08.00 4

Lim, S. A., \& You, S. (2019). Long-Term Effect of Parents' Support on Adolescents' Career Maturity. Journal of Career Development, 46(1), 48-61. https://doi.org/10.1177/0894845317731 866

Makmun, M. (2017). 87\% mahasiswa Indonesia salah jurusan. Retrived from http://www.beritasatu.com/nasional/44 8668-87-mahasiswa-indonesia-salahjurusan.html

Myers, David G.(2012). Psikologi Sosial.Salemba Humanika : Jakarta

Ogutu, J. O., Peter O., Samuel N. M. (2017). Selfefficacy as a predictor of career decision making among Secondary school students in busia county, Kenya. Journal of Education andf Practice, 8(11), 20-29. Retrived from www.iiste.org

Pappas, T. S., \& Kounenou, K. (2011). Career decision making of Greek post secondary vocational students: The impact of parents and career decision making selfefficacy. Procedia - Social and Behavioral Sciences, 15, 3410-3414. https://doi.org/10.1016/j.sbspro.2011.04 .310 
Putro, Z. K. (2017). Memahami Ciri dan Tugas Perkembangan Masa Remaja. Jurnal Aplikasi Ilmu-Ilmu Agama. 17 (1). 25-32. Retrived ftom ejournal.uin-suka.ac.id/

Reddan, G. (2015). Enhancing students' selfefficacy in making positive Career decisions. Asia-Pacific Journal of Cooperative Education, 16(4), 291-300. Retrived from https://eric.ed.gov

Riady, Mohammad Antos.(2014). Hubungan antara career self-efficacy dengan kematangan karir SMK Ahmad Yani Jabung. Skripsi. Universitas Islam Maulana Malik Ibrahim Malang Retrived from https://etheses.uin-malang.ac.id

Sagala, S. (2017). Human Capital : Membangun Modal Sumber Daya Manusia Berkarakter Unggul Melalui Pendidikan Berkualitas Depok: PT Kharisma Putra Mandiri

Santrock, J W. (2012). Life Span Development: Thirteenth Edition. University of Texas : Dallas : Mc Graw-Hill
Saragih, R. (2016). Ternyata 87\% mahasiswa di Indonesia salah memilih jurusan. Retrived from https://tanyakarir.com/2016/06/28/tern yata-87-mahasiswa-di-indonesia-salahmemilih-jurusan/

Schmitz, G \& Melodi, Rowbotham. (2013). Development and Validation of a Student Self-efficacy Scale. Journal of Nursing \& Care, 02(01). https://doi.org/10.4172/21671168.1000126

Soesandirejo. (2017). Dikotomi Timur dan Barat; Orang Tua, Anak, dan Keluarga. Retrived from http://www.wacana.co/2017/01/dikotom i-timur-dan-barat-orang-tua-anak-dankeluarga/

Tillman, Kristen. (2015). Parental Influence on College Students' Career Aspirations. University Honors Program Theses. 86. 